\title{
CORPORATE SOCIAL RESPONSIBILITY (CSR) DARI SUDUT PANDANG PERUSAHAAN
}

Oleh:

\author{
Meilanny Budiarti S. \& Santoso Tri Raharjo
}

\begin{abstract}
Abstrak
Corporate Social Responsibility (CSR) merupakan salah satu bagian dari Corporate Responsibility sehingga diminta atau tidak dan ada aturan atau tidak terkait dengan pelaksanaan CSR, pihak perusahaan akan tetap melakukan kegiatan CSR kepada masyarakat lokal.

Eksistensi perusahaan berpotensi besar mengubah lingkungan masyarakat, baik ke arah negatif maupun positif. Dengan demikian perusahaan perlu mencegah timbulnya dampak negatif, karena hal tersebut dapat memicu konflik dengan masyarakat, yang selanjutnya dapat mengganggu jalannya perusahaan dan aktifitas masyarakat.

Berbagai dampak sosial, ekonomi, dan lingkungan yang timbul akibat berdirinya suatu kawasan industri, mengharuskan perusahaan untuk bertanggung jawab kepada publik khususnya masyarakat di sekitar wilayah perusahaan melalui aktivitas yang nyata sehingga dalam pelaksanaan kegiatan CSR, perusahaan harus berhati-hati dan dilakukan dengan cara-cara yang benar agar tidak memperkuat kondisi relasi ketergantungan dari masyarakat akan kehadiran perusahaan.
\end{abstract}

\section{Kata kunci:}

CSR, tanggung jawab sosial, perusahaan, persepsi perusahaan, masyarakat

\section{A. PENDAHULUAN}

Masyarakat memiliki local wisdom yang berbeda di setiap daerah, sehingga program-program tanggung jawab sosial perusahaan harus disesuaikan dengan kondisi masyarakat setempat tersebut. Hal tersebut sebagai konsekuensi keberadaannya perusahaan sebagai 'agent of development' di tengah-tengah masyarakat. Dengan demikian, sangat penting bagi perusahaan untuk mengetahui kondisi-kondisi sosial budaya masyarakat sekitar.
Kegiatan-kegiatan tanggung jawab sosial (corporate social responsibility) perusahaan dengan demikian membutuhkan pemahaman yang baik dan mendalam mengenai kondisi masyarakat setempat dimana kegiatan corporate social responsibility (CSR) perusahaan tersebut diwujudkan. Peran serta masyarakat dan stakeholder menjadi penting untuk dilibatkan dalam pelaksanaan kegiatan CSR tersebut. Kegiatan CSR bagi masyarakat merupakan suatu proses yang bergerak dan bertalian dengan sumber-sumber yang ada di masyarakat, yang saat ini mulai 
dimanfaatkan secara maksimal oleh perusahaan.

Di sisi lain, tanggung jawab sosial merupakan salah satu bagian dari corporate responsibility sehingga diminta atau tidak dan ada aturan atau tidak terkait dengan pelaksanaan corporate social responsibility (CSR), pihak perusahaan akan tetap melakukan kegiatan CSR kepada masyarakat lokal. Namun, pada praktiknya, program CSR yang dilakukan oleh perusahaan masih banyak yang cenderung ditujukan untuk 'meredam' munculnya gejolak atau konflik antara masyarakat dengan perusahaan.

Pelaksanaan otonomi daerah juga memunculkan persoalan tersendiri yang harus dihadapi oleh perusahaan multinasional di daerah. Seiring pula dengan meningkatnya kesadaran masyarakat akan hak-haknya untuk turut serta mengatur penyelenggaraan negara, masyarakat mulai ingin memperoleh manfaat dari keberadaan perusahaan yang beroperasi di daerahnya. Hal ini didukung oleh tuntutan penerapan konsep CSR baik secara lokal melalui berbagai aksi masyarakat, secara nasional melalui legitimasi hukum, serta iklim perindustrian di seluruh penjuru dunia.

Dalam penerapan CSR oleh perusahaan, perlu hati-hati dan cara-cara yang benar agar tidak memperkuat kondisi relasi ketergantungan dari masyarakat akan kehadiran perusahaan. Keuntungankeuntungan yang secara otomatis didapat dari pelaksanaan kegiatan CSR bagi masyarakat di sini adalah adanya pengurangan resiko, meningkatnya good will, mengurangi biaya, membangun sumber daya manusia, serta meningkatkan kesejahteraan masyarakat.

\section{B. CORPORATE SOCIAL RESPONSIBILITY}

Penerapan kegiatan corporate social responsibility didasarkan pada banyak alasan dan tuntutan, sebagai paduan antara faktor internal dan eksternal. Sebagaimana dijelaskan lebih jauh oleh Frynas (2009) yang melihat bahwa pertimbangan perusahaan untuk melakukan kegiatan CSR antara lain umumnya karena alasan-alasan berikut:

1) Untuk memenuhi regulasi, hukum dan aturan

2) Sebagai investasi sosial perusahaan untuk mendapatkan image yang positif

3) Bagian dari strategi bisnis perusahaan

4) Untuk memperoleh licence to operate dari masyarakat setempat

5) Bagian dari risk management perusahaan untuk meredam dan menghindari konflik sosial

Terkait dengan batasan mengenai tanggung jawab sosial perusahaan atau Corporate Social Responsibility (CSR) yang dikemukakan oleh para ahli berbeda-beda, sesuai dengan sudut pandang dan pemahaman masing-masing mengenai CSR. Namun demikian perlu dikemukakan beberapa definisi, sebagai koridor dan memagari kajian mengenai CSR. Berikut definisi CSR yang dikemukakan oleh Pemerintah Inggris: 
"The voluntary actions that business can take, over and above compliance with minimum requirements, to address both its own competitive interest and interests of wider society" (www.csr.gov.uk UK Government)

Lebih lanjut World Business Council and Sustainability Development (WBCSD), memberikan pengertian tanggung jawab sosial perusahaan sebagai berikut:

"The continuing commitment by business to behave ethically and contribute to economic development while improving the quality of life of the workforce and their families as well as of the local community and society at large"(WBCSD, 1999, Business Association)

Pendapat tanggung jawab sosial lainnya dikemukakan dalam www.csrasia.com, sebagai berikut:

"A company's commitment to operating in an economically, socially, and environmentally sustainable manner while balancing the interests of the diverse stakeholders" (www.csrasia.com, social enterprise)

Definisi-definisi tersebut menunjukkan adanya keragaman dalam mengartikan dan mengimplementasikan CSR, sehingga, hingga saat ini tidak ada terdapat kesepakatan mengenai batasan tanggung jawab sosial perusahaan (McWilliams, et.al, dalam Radyati, M.R. \& Nindita. 2008). Namun demikian terdapat suatu pemahaman yang sama di masyarakat Eropa mengenai CSR, sebagaimana pernyataan berikut:

"There is broad agreement in Europe on the definition of CSR as a concept whereby companies integrate social and environmental concerns - on a voluntary basis- into their business operations as well as their interactions with stakeholders".(European Communities 2007)

Berdasarkan definisi-definisi tersebut dapat ditarik inti bahwa CSR merupakan konsep sebagai berikut:

1) Perusahaan harus mempunyai perhatian terhadap persoalan sosial dan lingkungannya

2) Berdasarkan prinsip sukarela

3) Kegiatan bisnis dan interaksi dengan pemangku kepentingan harus memperhatikan persoalan sosial dan lingkungan

Setidaknya ada 2 (dua) landasan berkenaan dengan corporate social responsibility (CSR) yaitu berasal dari etika bisnis (bisa berdasarkan agama, budaya atau etika kebaikan lainnya) dan dimensi sosial dari aktivitas bisnis. CSR atau sering diartikan sebagai "being socially responsible" jelas merupakan suatu cara-cara yang berbeda untuk orang yang berbeda dalam negara yang berbeda pula. Artinya penerapan CSR di masing-masing negara harus disesuaikan dengan konteks sosial dan lingkungannya. Sehingga perlu kehati-hatian dalam menerapkan konsep CSR dari negaranegara maju di negara-negara yang sedang berkembang (Frynas, 2009).

Blowfield dan Frynas mengibaratkan CSR sebagai sebuah 'payung' bagi beragam teori dan praktek yang mengakui dan memahami persoalanpersoalan berikut:

1) Bahwa perusahaan memiliki tanggung jawab terhadap dampaknya terhadap masyarakat dan lingkungan alam, yang terkadang lebih jauh lagi 
sekedar memenuhi aspek legal dan pertanggungjawaban individual.

2) Bahwa perusahaan memiliki suatu tanggung jawab untuk berperilaku dengan siapa mereka melakukan bisnis.

3) Bahwa bisnis harus (perlu) mengelola hubungannya dengan masyarakat yang lebih luas, dengan alasan komersial atau untuk nilai tambah terhadap masyarakat.

Sebagai konsep 'payung' maka menjadi hal yang lumrah ketika melihat banyak dan beragamnya pengertian dan pemahaman mengenai CSR, memunculkan banyak interpretasi mengenai CSR sebagaimana yang dikemukakan oleh Ameshi and Adi, 2007 dan dikutip oleh Frynas (2009:5), yaitu:

1) Etika dan moralitas bisnis

2) Akuntabilitas perusahaan

3) Corporate citizenship (perusahaan warga)

4) Bantuan dan pilantropi perusahaan

5) Perusahaan hijau dan pemasaran hijau

6) Manajemen keragaman

7) Tanggungjawab lingkungan

8) Hak asasi manusia

9) Rantai manajemen pembelian dan penyediaan yang bertanggungjawab

10) Investasi sosial yang bertanggung jawab

11) Perjanjian (kesepakatan) stakeholder

12) Keberlanjutan

Sementara itu, Garriga \& Mele (2004:

51-71) mencoba memetakan konsep-konsep

CSR ke dalam empat kelompok besar, sebagai berikut:

1) Kelompok pertama yang berasumsi bahwa perusahaan adalah instrumen untuk menciptakan kesejahteraan dan bahwa ini merupakan satu-satunya tanggung jawab sosial. Hanya aspek ekonomi dari interaksi antara bisnis dan masyarakat yang dipertimbangkan. Jadi sekiranya terdapat aktivitas sosial yang diterima, jika dan hanya jika hal tersebut konsisten dengan penciptaan kesejahteraan. Kelompok teori ini dapat disebut instrumental theories karena mereka memahami CSR sebagai alat belaka untuk memperoleh keuntungan.

2) Kelompok kedua yang melihat kekuatan sosial dari perusahaan yang menjadi tekanan, khususnya dalam hubungannya dengan masyarakat dan tanggung jawabnya dalam arena politis berkaitan dengan kekuatan ini. Hal tersebut mengarahkan perusahaan untuk menerima tugastugas dan hak-hak sosial atau berpartisipasi dalam kerjasama sosial tertentu. Kita dapat menyebut kelompok ini dengan political theories.

3) Kelompok ketiga termasuk teori-teori yang mempertimbangkan bisnis seharusnya to integrate tuntutan sosial. Biasanya berpendapat bahwa bisnis tergantung pada masyarakat untuk kelanjutan dan pertumbuhannya, bahkan untuk keberadaan bisnisnya sendiri. Kelompok ini adalah integrative theories.

4) Kelompok keempat teori dari pemahaman hubungan antara bisnis dan masyarakat adalah penanaman nilai-nilai etis. Hal tersebut mengarahkan visi CSR dari suatu perspektif etis dan sebagai konsekuensinya, perusahaan harus menerima tanggung jawab sosial sebagai sebuah kewajiban etis di atas pertimbangan lainnya. kelompok ini disebut dengan ethical theories

\section{Instrumental CSR}

Kelompok pertama, kelompok instrumental theories, menganggap bahwa CSR atau kegiatan sosial adalah sebuah alat untuk mencapai tujuan ekonomi yang pada akhirnya adalah menghasilkan kekayaan. Pendekatan instrumental theories ini didukung oleh pandangan yang diungkapkan oleh Friedman (1970) bahwa satu-satunya 
tanggung jawab bisnis kepada masyarakat adalah memaksimalkan profit untuk para pemegang saham, sesuai dengan kerangka hukum dan kebiasaan etika dari negara tempat bisnis tersebut berada. Kelompok teori ini kemudian banyak diakui dan diterima oleh perusahaan, bahkan banyak perusahaan yang melakukan program CSR dengan menggunakan dasar teori ini. Sebagaimana yang diungkapkan oleh Windsor (2001: hal. 226) bahwa "a leit-motiv of wealth creation progressively dominates the managerial conception of responsibility".

Ada tiga tujuan ekonomi yang kemudian dapat diidentifikasi dari kelompok instrumental theories ini menurut Garriga \& Mele (2004: 53) yaitu maximization of shareholder value; the strategic goal of achieving competitive advantages; dan cause-related marketing. Dalam tujuan maximization of shareholder value, Garriga \& Mele (2004) menjelasan bahwa investasi untuk menjawab tuntutan sosial yang akan meningkatkan nilai para investor dimata masyarakat harus dilakukan, sedangkan jika tuntutan sosial tersebut mengakibatkan kerugian bagi perusahaan, maka investasi tersebut seharusnya ditolak. Konsep ini memuat tujuan untuk pencarian nilai atau value-seeking atau long-term values maximization sebagai tujuan utamanya dan pada saat yang bersamaan, tujuan ini digunakan sebagai kriteria dalam transaksi penting diantara para pemangku kepentingan (Jensen, 2000; Garriga \& Mele, 2004).
Dalam tujuan the strategic goal of achieving competitive advantages, perusahaan fokus kepada bagaimana mengalokasikan sumber daya untuk mencapai tujuan sosial jangka panjang dan menciptakan keuntungan yang kompetitif. Hal ini sesuai dengan yang diungkapkan oleh Husted \& Allen, 2000, yang dikutip oleh Garriga \& Mele (2004:54) “... focused on how to allocate resources in order to achieve longterm social objectives and create competitive advantage". Ada tiga pendekatan yang dapat digunakan dalam mencapai tujuan tersebut, yaitu social investments in a competitive context melalui philanthropic activities; natural resource-based view of the firm and dynamic capabilities melalui unique interplay of human, organizational and physical resources over time; dan strategies for the bottom of the economic pyramid melalui disruptive innovations (Garriga \& Mele, 2004; Porter \& Kramer, 2002; Christensen, et al., 2001; Christensen \& Overdorf, 2000; Barney, 1991; Wernerfelt, 1984).

Cause-related marketing, merupakan sebuah proses kegiatan pemasaran perusahaan yang menghasilkan keuntungan melalui adanya pertukaran yang menguntungkan yang sesuai dengan tujuan perusahaan dan juga individual. Misalnya dengan menjual produk dengan label bebas pestisida atau non-animal tested. Varadjan \& Menon (1988:60) mendefinisikan causerelated marketing sebagai:

The process of formulating and implementing marketing activities that are characterized by an offer from the 
firm to contribute a specified amount to a designated cause when costumers engage in a revenueproviding exchange that satisfy organizational and invididual objectives.

Tujuan dari cause-related marketing dari berbagai hasil penelitian yang dilakukan adalah meningkatkan pendapatan perusahaan dan penjualan atau hubungan konsumen dengan membangun merk perusahaan melalui akuisisi dan asosiasi dengan dimensi etika atau dimensi tanggung jawab sosial, sehingga menghasilkan situasi yang saling menguntungkan, dalam konteks perusahaan dan sosial (Gerriga \& Mele, 2004; Murray \& Montanari, 1986; Varadarajan \& Menon, 1988).

\section{Politik CSR}

Kelompok teori kedua yang dipetakan oleh Garriga \& Mele (2004) adalah kelompok political theories. Kelompok teori ini memusatkan perhatiannya pada bagaimana menggunakan tanggung jawab dari kekuatan bisnis dalam arena politik. Yang dimaksud dengan political theories, menurut Garriga \& Mele (2004:55) adalah "a group of CSR theories and approaches focus on interactions and connections between business and society and on the power and position of business and its inherent responsibility". (sekelompok teori-teori dan pendekatan CSR yang memusatkan perhatiannya pada interaksi dan koneksi antara bisnis dan masyarakat dan pada kekuasaan dan posisi bisnis dan tanggung jawab yang melekat pada bisnis tersebut). Ada tiga teori utama yang diungkapkan oleh
Garriga \& Mele (2004), yaitu Corporate Constitutionalism, Integrative Social Contract Theory dan Corporate Citizenship.

\section{Teori Corporate Constitutionalism} pertama kali dikemukakan oleh Davis (1960). la adalah orang pertama yang berpendapat bahwa bisnis adalah institusi sosial dan sehingga bisnis harus menggunakan kekuasaannya secara bertanggung jawab. Garriga \& Mele (2004:55) mengungkapkan bahwa Davis (1960) "was one of the first to explore the role of power that business has in society and the social impact of this power". Kemudian Davis (1960) memperkenalkan kekuatan bisnis sebagai sebuah elemen baru dalam debat mengenai CSR. Davis (1960) menekankan pada pendapat bahwa tanggung jawab sosial bisnis tergantung pada kekuasaan sosial yang dimiliki bisnis tersebut. Hal ini kemudian diperkuat dengan yang diungkapkan oleh Davis (1967:48) "social responsibilities of businessmen arise from the amount of social power that they have ....the equation of social power responsibility has to be understood through the functional role of business and managers". Ini berarti bahwa tanggung jawab sosial kekuasaan dimanifestasikan melalui peran fungsional bisnis dan manager dalam masyarakat.

Teori integrative social contract theory yang diungkapkan oleh Donaldson \& Dunfee (1994, 1999) berawal dari pertimbangan bahwa ada hubungan antara bisnis dan masyarakat berdasarkan pada tradisi kontrak sosial. Kontrak sosial ini kemudian 
berimplikasi kepada beberapa kewajiban tidak langsung dari bisnis untuk masyarakat (Garriga \& Mele, 2004; Prayogo, 2011). Lebih lanjut, teori ini mengungkapkan sebuah proses yang memberikan legitimasi kepada kontrak yang terjadi diantara sistem industri, departemen, dan ekonomi (Garriga \& Mele, 2004). Sementara itu, Prayogo (2011:74) mengungkapkan bahwa:

Kontrak sosial merupakan
kesepakatan yang bersifat "implicit"
masyarakat memberikan legitimasi
sosial (the right to exist) atas
kehadiran korporasi dan sebaliknya
manfaat ekonomi yang dihasilkan
bisnis harus terdistribusi pula kepada
masyarakat (in return for certain
benefits).

Sementara itu, teori corporate citizenship lebih memusatkan perhatiannya pada hak-hak, tanggung jawab dan kemungkinan partnership dari bisnis dalam masyarakat. Sebelumnya, corporate citizenship selalu dikaitkan dengan "a sense of belonging to a community" atau rasa kepemilikan kepada sebuah masyarakat (Matten, et al., 2003; Wood \& Lodgson, 2002), sehingga sudah menjadi hal yang biasa diantara para manager dan pengelola bisnis untuk melihat bahwa bisnis perlu memperhatikan masyarakat tempat bisnis itu beroperasi. Oleh karena itu, menurut teori ini, bisnis dipahami sebagai seperti warga dengan keterlibatan tertentu dalam masyarakat.

\section{Integratif CSR}

Kelompok teori ketiga yang diungkapkan oleh Garriga \& Mele (2004) adalah kelompok integrative theories. Kelompok ini berpendapat bahwa bisnis sangat tergantung pada masyarakat untuk menjaga keberadaan, keberlanjutan dan perkembangan bisnis tersebut. Integrative theories memandang pada bagaimana bisnis mengintegrasikan tuntutan sosial dan biasanya fokus kepada mendeteksi, mencari dan memberikan respon kepada tuntutan sosial untuk mencapai legitimasi sosial, penerimaan sosial yang lebih tinggi dan prestige (Garriga \& Mele, 2004). Pendekatan yang diurai dalam kelompok teori ini adalah issues management, the principle of public responsibility, stakeholder management dan corporate social performance (Garriga \& Mele, 2004:58-59).

Issues management menurut Wartick \& Rude (1986:124) diartikan sebagai "the processes by which the corporation can identify, evaluate and respond to those social and political issues which may impact significantly upon it'. Issues management merupakan pelebaran dari konsep social responsiveness yang muncul di tahun 1970an (Sethi, 1975). Konsep social responsiveness ini menekankan pada pentingnya untuk menutupi gap diantara apa yang diharapkan oleh masyarakat kepada perusahaan dan apa yang perusahaan lakukan secara aktual. Gap ini biasanya ada dalam zona yang disebut Ackerman (1973:92) sebagai "zone of discretion (neither 
regulated nor illegal nor sanctioned) where the company receives some unclear signals from the environment". Ini berarti bahwa issues management menekankan pada proses memberikan respon dari pihak perusahaan terhadap masalah-masalah sosial dan bahwa issues management berfungsi sebagai peringatan dini atas potensi munculnya ancaman-ancaman lingkungan dan juga kesempatankesempatan, sehingga dapat meminimalisir kejutan dari adanya perubahan sosial dan politik (Garriga \& Mele, 2004).

Pendekatan the principle of public responsibility pertama kali diungkapkan oleh Preston \& Post $(1975$, 1981). Mereka menekankan pada kegunaan kata "public" daripada "social", untuk menunjukkan pada pentingnya proses publik dalam mendefinisikan scope dari tanggung jawab, daripada pandangan personal-morality atau berdasarkan minat kelompok tertentu saja (Garriga \& Mele, 2004:58). Preston \& Post dalam Garriga \& Mele (2004) berpendapat bahwa aturan yang sesuai untuk melegitimasi perilaku manajerial dapat ditemukan dalam kerangka kebijakan publik yang relevan dan bahwa kebijakan publik tidak hanya berisi aturan-autran dan perundang-undangan tetapi juga mengandung pola yang sangat luas dari arah sosial yang terefleksikan dalam opini publik, isu-isu yang muncul, kebutuhan akan hukum formal dan praktik-praktik dukungan atau implementasi.

Pendekatan berikutnya adalah pendekatan stakeholder management.
Pendekatan ini berorientasi kepada para stakeholders atau pihak-pihak atau orangorang yang mempengaruhi dan atau dipengaruhi oleh kebijakan dan praktik sebuah perusahaan. Pendekatan Stakeholder management baru berkembang secara akademik di akhir tahun 1970-an. Di tahun 1978, Emshoff \& Freeman (Garriga \& Mele, 2004: 59) mempresentasikan dua prinsip dasar yang memperkuat pendekatan ini, yaitu achieving maximum cooperation between entire system of stakeholder groups and the objectives of the corporation; and efforts in dealing with issues affecting multiple stakeholders. Pendekatan ini mencoba mengintegrasikan kelompokkelompok dengan kepentingan-kepentingan perusahaan ke dalam pembuatan keputusan managerial (Garriga \& Mele, 2004). Di masa awal munculnya pendekatan ini, banyak korporasi yang ditekan oleh NGO, aktifis, masyarakat, pemerintah, media dan kelompok-kelompok lainnya untuk melakukan kegiatan yang disebut sebagai responsible corporate practices (Garriga \& Mele, 2004:59). Namun sekarang, berbagai perusahaan berusaha mencari jawaban dari berbagai tuntutan sosial melalui dialog dengan beragam stakeholders. Dialog antar stakeholder membantu menjawab pertanyaan mengenai responsiveness dari perusahaan dalam menerima sinyal yang kurang jelas dari lingkungan. Kaptein \& Van Tulder (2003:208) menambahkan "this dialogue not only enhances a company's sensitivity to its environment but also 
increases the environments understanding of the dilemmas facing the organization".

Pendekatan corporate social performance juga merupakan sebuah pendekatan yang mencari legitimasi sosial. Carroll (1979) yang memperkenalkan pendekatan ini yang terdiri dari 3 elemen, yaitu definisi dasar dari tanggung jawab sosial, daftar isu yang memunculkan tanggung jawab sosial, dan filosofi dari respon terhadap isu-isu sosial (Garriga \& Mele, 2004). Sementara itu, Wartich \& Cochran (1985) menambahkan pendekatan Carroll dengan menyarankan bahwa corporate social involvement mengandung prinsip-prinsip social responsibility, the process of social responsiveness and the policy of issues management (Garriga \& Mele, 2004:60). Perkembangan terkini dari pendekatan ini kemudian diungkapkan oleh Wood (1991) yang menyebutkan bahwa corporate social performance terdiri dari prinsip-prinsip CSR, proses dari corporate social responsivenesss dan hasil dari perilaku perusahaan.

\section{Etik CSR}

Kelompok teori terakhir untuk memetakan konsep-konsep CSR adalah ethical theories. Teori-teori yang tercakup dalam kelompok ini berperan sebagai perekat hubungan diantara perusahaan dan masyarakat. Teori-teori ini merupakan prinsip-prinsip yang mengungkapkan mengenai hal-hal yang benar untuk dilakukan atau hal-hal yang perlu dilakukan untuk mencapai masyarakat yang sejahtera.

Pendekatan pertama adalah normative stakeholder theory. Teori ini menekankan pada perlunya referensi dari berbagai teori moral yang ada, seperti misalnya Kantian moral teori, konsep Libertian, prinsip-prinsip keadilan, dan masih banyak lagi. Donaldson \& Preston (1995: 67) menyebutkan bahwa stakeholder theory memiliki inti normative yang berdasarkan pada dua ide utama, yaitu "(1) stakeholders are persons or groups with legitimate interests in procedural and/or substantive aspects of corporate activity and (2) the interests of all stakeholders are of intrinsic values". Berdasarkan hal tersebut, maka dalam praktik CSR dengan menggunakan pendekatan stakeholder teori, etika atau moral merupakan pusat dari praktik tersebut.

Pendekatan Universal Rights melalui Hak Asasi Manusia telah diambil sebagai dasar bagi CSR (Cassel, 2001; Garriga \& Mele, 2004). Kini, banyak tanggung jawab sosial yang dijalankan dikembangkan dengan menggunakan pendekatan hak asasi manusia. Selain hak asasi manusia, pendekatan ini juga mendasarkan pada hakhak buruh dan juga perlindungan lingkungan.

Pendekatan

pembangunan

berkelanjutan atau sustainable development dimasukkan ke dalam kelompok ethical teori karena konsep pembangunan berkelanjutan menyebutkan bahwa pembangunan berkelanjutan bertujuan untuk menjawab kebutuhan di masa kini tanpa mengancam 
kemampuan untuk melindungi generasi penerus untuk memenuhi kebutuhannya. Istilah sustainable development muncul pada tahun 1987 dalam "Brutland Report". Pada awalnya, pembangunan berkelanjutan menitikberatkan pada faktor lingkungan, namun, World Business Council for Sustainable Development (2002:2) menyebutkan bahwa "sustainable development requires the integration of social, environmental, and economic considerations to make balanced judgements for the long term". Kaitannya dengan CSR adalah, seperti yang diungkapkan oleh Wheeler, et al. (2003:17) bahwa

Sustainability is an ideal toward which society and business can continually strive, the way we strive is by creating value, creating outcomes that are consistent with the ideal of sustainability along social environmental and economic dimensions.

Dengan demikian, secara etika, CSR perusahaan harus menggunakan pendekatan "triple bottom line", yaitu memasukkan aspek ekonomi, sosial dan lingkungan, sehingga akan dapat menjamin keberlanjutan perusahaan tanpa merusak keberlanjutan lingkungan dan masyarakat.

Pendekatan terakhir dalam kelompok ethical theories adalah pendekatan common good (kebajikan umum). Pendekatan ini merupakan pendekatan klasik yang berakar pada tradisi Aristotelian yang kemudian dijadikan referensi kunci untuk etika bisnis (Smith, 1999; Alford \& Naughton, 2002; Mele, 2002). Pendekatan ini menyebutkan bahwa perusahaan, sebagaimana kelompok sosial atau individual dalam masyarakat, harus berkontribusi untuk kebajikan umum, karena sudah menjadi bagian dari masyarakat. Perusahaan dapat berkontribusi untuk kebajikan umum dengan berbagai macam cara, sebagaimana yang diungkapkan oleh Garriga \& Mele (2004:62):

"....creating wealth, providing goods and services in an efficient and fair way, at the same time respecting the dignity and the inalienable and fundamental rights of the individual'.

Dari uraian sebelumnya, dapat ditarik benang merah bahwa banyak teori-teori CSR fokus kepada 4 aspek utama, sebagaimana yang diungkapkan oleh Garriga \& Mele (2004:65) yaitu: (1) meeting objectives that produce long-term profits, (2) using business power in a responsible way, (3) integrating social demands and (4) contributing to a good society by doing what is ethically correct.

Dalam tabel 2.1. dikemukakan secara ringkas mengenai teori-teori dan pendekatanpendekatan yang berkaitan dengan tanggung jawab sosial perusahaan menurut Garriga and Mele (2004). Tabel tersebut sekaligus merangkum penjelasan-penjelasan sebelumnya, baik teori instrumental, teori politik, teori integratif dan teori etik mengenai CSR 
Tabel 2.1

Corporate Social Responsibilities Theories and Related Approaches

\begin{tabular}{|c|c|c|c|c|c|}
\hline \multicolumn{3}{|c|}{ Jenis Teori } & \multirow{2}{*}{$\begin{array}{l}\text { Pendekatan } \\
\text { Maksimalisasi } \\
\text { nilai shareholder }\end{array}$} & \multirow{2}{*}{\begin{tabular}{l}
\multicolumn{1}{c}{ Penjelasan Singkat } \\
$\begin{array}{l}\text { Maksimalisasi nilai jangka } \\
\text { panjang }\end{array}$
\end{tabular}} & $\begin{array}{c}\text { Beberapa Referensi } \\
\text { Kunci }\end{array}$ \\
\hline \multirow[t]{5}{*}{1.} & \multirow{3}{*}{\multicolumn{2}{|c|}{$\begin{array}{l}\text { Intrumental } \\
\text { theories (fokus } \\
\text { pada pencapaian } \\
\text { sasaran ekonomi } \\
\text { melalui aktifitas } \\
\text { sosial) }\end{array}$}} & & & $\begin{array}{l}\text { Friedman } \\
\text { Jensen (2000) }\end{array}$ \\
\hline & & & $\begin{array}{l}\text { 2. Strategi untuk } \\
\text { keuntungan } \\
\text { kompetitif }\end{array}$ & $\begin{array}{ll}\text { - } & \text { Investasi sosial dalam } \\
\text { konteks kompetitif }\end{array}$ & $\begin{array}{l}\text { Porter and Kramer } \\
(2002)\end{array}$ \\
\hline & & & & $\begin{array}{l}\text { - Strategi berdasarkan } \\
\text { pandangan sumber } \\
\text { alami dari perusahaan } \\
\text { dan dinamika } \\
\text { kapabilitas perusahaan }\end{array}$ & Hart (1995), Lizt (1996 \\
\hline & & & & $\begin{array}{l}\text { - Strategi dari dasar } \\
\text { piramida ekonomi }\end{array}$ & $\begin{array}{lr}\text { Prahalad } & \text { and } \\
\text { Hammond } & (2002), \\
\text { Hart and } & \text { Christensen } \\
(2002), & \text { Prahalad } \\
(2003) & \\
\end{array}$ \\
\hline & & & $\begin{array}{l}\text { 3. Caused-related } \\
\text { marketing }\end{array}$ & $\begin{array}{l}\text { Pengakuan aktifitas sosial } \\
\text { altruistik dimanfaatkan } \\
\text { sebagai alat pemasaran }\end{array}$ & $\begin{array}{l}\text { Varadarajan and } \\
\text { Menon (1986), Murray } \\
\text { and Montanari (1986) }\end{array}$ \\
\hline \multirow[t]{3}{*}{2.} & \multirow{3}{*}{$\begin{array}{l}\text { Political } \\
\text { theories } \\
\text { (fokus pada } \\
\text { pemanfaatan } \\
\text { tanggung } \\
\text { jawab } \\
\text { kekuatan } \\
\text { bisnis dalam } \\
\text { arena politik) }\end{array}$} & & $\begin{array}{l}\text { Konstitusiona- } \\
\text { lisme perusahaan } \\
\text { (Corporate } \\
\text { constitutiona-lism) }\end{array}$ & $\begin{array}{l}\text { Tanggung jawab sosial bisnis } \\
\text { muncul dari sejumlah } \\
\text { kekuatan sosial yang mereka }\end{array}$ & Davis $(1960,1967)$ \\
\hline & & & $\begin{array}{l}\text { Teori Kontrak } \\
\text { Sosial Integrative } \\
\text { (integrative social } \\
\text { contract theories) }\end{array}$ & $\begin{array}{l}\text { Asumsinya bahwa terdapat } \\
\text { suatu kontrak sosial antara } \\
\text { perusahaan dan masyarakat }\end{array}$ & $\begin{array}{l}\text { Donaldson \& Dunfee } \\
(1994,1999)\end{array}$ \\
\hline & & & $\begin{array}{l}\text { Corporate (or } \\
\text { business) } \\
\text { citizenship }\end{array}$ & $\begin{array}{l}\text { Perusahaan dipahami } \\
\text { sebagaimana seorang warga } \\
\text { dengan keterlibatan tertentu } \\
\text { dalam komunitas }\end{array}$ & 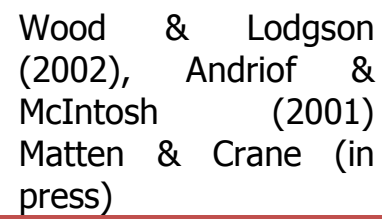 \\
\hline \multirow[t]{2}{*}{3.} & \multirow[t]{2}{*}{$\begin{array}{l}\text { Integrative } \\
\text { theories } \\
\text { (fokus } \\
\text { integrasi } \\
\text { tuntutan } \\
\text { sosial) }\end{array}$} & & $\begin{array}{l}\text { Manajemen isu } \\
\text { (issues } \\
\text { management) }\end{array}$ & $\begin{array}{l}\text { Proses-proses perusahaan } \\
\text { merespon isu sosial dan politik } \\
\text { yang mempengaruhinya. }\end{array}$ & $\begin{array}{l}\text { Sethi (1975), } \\
\text { Ackerman (1973), } \\
\text { Jones (1980), Vogel } \\
\text { (1986), Wartick and } \\
\text { Mahon (1994) }\end{array}$ \\
\hline & & & $\begin{array}{l}\text { Tanggung jawab } \\
\text { publik (public } \\
\text { responsibility) }\end{array}$ & $\begin{array}{l}\text { Hukum dan adanya proses } \\
\text { kebijakan publik diambil } \\
\text { sebagai rujukan untuk kinerja } \\
\text { sosial (social performance) }\end{array}$ & $\begin{array}{l}\text { Preston and Post } \\
(1975,1981)\end{array}$ \\
\hline
\end{tabular}


Lanjutan tabel: Tabel 2.1

\begin{tabular}{|c|c|c|c|c|c|}
\hline & & $\begin{array}{l}\text { Manajemen } \\
\text { Pemangku } \\
\text { Kepentingan } \\
\text { (stakeholder } \\
\text { management) }\end{array}$ & \multicolumn{2}{|l|}{$\begin{array}{l}\text { Kesimbangan para pemangku } \\
\text { kepentingan }\end{array}$} & $\begin{array}{l}\text { Mitchell et.al. (1997), } \\
\text { Agle and Mitchell } \\
\text { (1999), Rowley } \\
\text { (1997), }\end{array}$ \\
\hline & 4. & $\begin{array}{l}\text { Kinerja Sosial } \\
\text { Perusahaan } \\
\text { (Corporate social } \\
\text { performance) }\end{array}$ & \multicolumn{2}{|l|}{$\begin{array}{l}\text { Mencari legitimasi sosial dan } \\
\text { proses-proses untuk memberi } \\
\text { respon yang tepat terhadap } \\
\text { isu-isu sosial }\end{array}$} & $\begin{array}{l}\text { Carrol (1979), Wartick } \\
\text { and Cochran (1985), } \\
\text { Wood (1991b), } \\
\text { Swanson (1995) }\end{array}$ \\
\hline \multirow{4}{*}{$\begin{array}{l}\text { 4. Ethical } \\
\text { theories } \\
\text { (fokus pada } \\
\text { sesuatu yang } \\
\text { baik untuk } \\
\text { mencapai } \\
\text { suatu } \\
\text { masyarakat } \\
\text { yang baik) }\end{array}$} & 1. & $\begin{array}{l}\text { Teori Normatif } \\
\text { Pemangku } \\
\text { Kepentingan } \\
\text { (Stakeholder } \\
\text { normative } \\
\text { theories) }\end{array}$ & $\begin{array}{l}\text { Pertimbangan tugas- } \\
\text { tugas yang tergadai dari } \\
\text { perusahaan. Aplikasinya } \\
\text { membutuhkan rujukan } \\
\text { sejumlah teori moral }\end{array}$ & \multicolumn{2}{|c|}{$\begin{array}{l}\text { Freeman (1984, 1994), Evan } \\
\text { and Freeman (1988), } \\
\text { Donaldson and Preston } \\
\text { (1995), Freeman and } \\
\text { Phillips (2002), Phillips et al. } \\
\text { (2003) }\end{array}$} \\
\hline & 2. & $\begin{array}{l}\text { Hak-hak Azasi } \\
\text { Universal }\end{array}$ & $\begin{array}{l}\text { Kerangkanya } \\
\text { berdasarkan hak-hak } \\
\text { azasi manusia, hak buruh } \\
\text { dan penghargaan } \\
\text { lingkungan }\end{array}$ & \multicolumn{2}{|c|}{$\begin{array}{l}\text { The Global Sullivan } \\
\text { Principles (1999), UN Global } \\
\text { Compact (1999) }\end{array}$} \\
\hline & 3. & $\begin{array}{l}\text { Pembangunan } \\
\text { Berkelanjutan }\end{array}$ & $\begin{array}{l}\text { Upaya mencapai } \\
\text { pembangunan manusia } \\
\text { berdasarkan } \\
\text { pertimbangan saat ini } \\
\text { dan generasi masa depan }\end{array}$ & \multicolumn{2}{|c|}{$\begin{array}{l}\text { World Commission on } \\
\text { Environment and } \\
\text { Development (Brutland } \\
\text { Report) (1987), Gladwin anc } \\
\text { Kennelly (1995) }\end{array}$} \\
\hline & 4. & $\begin{array}{l}\text { The Common } \\
\text { good }\end{array}$ & $\begin{array}{l}\text { Berorientasi pada } \\
\text { kebiasaan baik } \\
\text { masyarakat }\end{array}$ & \multicolumn{2}{|c|}{$\begin{array}{l}\text { Alford and Naugghton } \\
(2002), \text { Mele (2002) Kaku } \\
(1997)\end{array}$} \\
\hline
\end{tabular}

Sumber: Garriga \& Mele, 2004: 63-64

\section{PERSEPSI PERUSAHAAN TERHADAP KEGIATAN CSR}

Keberadaan perusaaan di tengah lingkungan masyarakat berpengaruh langsung dan tidak langsung terhadap lingkungan eksternal yaitu masyarakat. Eksistensi perusahaan berpotensi besar mengubah lingkungan masyarakat, baik ke arah negatif maupun positif. Dengan demikian perusahaan perlu mencegah timbulnya dampak negatif, karena hal tersebut dapat memicu konflik dengan masyarakat, yang selanjutnya dapat mengganggu jalannya perusahaan dan aktifitas masyarakat.

Pada dasarnya tidak ada perspektis teoritis atau metodologi kajian yang dapat menjelaskan aktifitas CSR secara memuaskan menjawab semua pertanyaan (Lockett et al.2006, p.12). Namun demikian terdapat terdapat dua teori dan satu perspektif yang berkembang saat ini dalam CSR sebagaimana yang diungkapkan oleh Frynas (2009), yaitu: 
1) Teori Stakeholder: menekankan reaksi perusahaan (perseorangan) dalam konteks hubungan dengan stakeholder eksternal. Teori ini menjelaskan respon strategis yang berbeda dari perusahaan terhadap tekanan-tekanan sosial walaupun dalam industri sejenis atau negara yang sama, berdasarkan pada sifat hubungan eksternal.

2) Teori Institusional: menekankan daya adaptif perusahaan secara kelembagaan (aturan). Teori ini menjelaskan mengapa perusahaan dari negara atau industri berbeda dalam merespon tekanan sosial dan lingkungan, dan mengapa di negara yang berbeda-beda dari perusahaan multinasional yang sama memilih strategi CSR yang berbeda, sebagai hasil dari pemberlakuan norma atau keyakinan nasional.

3) Perspektif Austrian Economics: perspektif ini menyediakan wawasan terhadap upaya strategi aktif CSR dalam perusahaan dengan suatu perspektif kewirausahaan.

Teori Stakeholder dan Teori Institusional dapat membantu menjelaskan bagaimana respon perusahaan terhadap tekanan kondisi sosial eksternal dan lingkungan. Namun demikian gagal untuk menjelaskan pilihan strategi aktif dalam perusahaan, yaitu mengapa perusahaan tertentu menggunakan CSR sebagai sebuah senjata melawan persaingan perusahaan atau mengapa perusahaan tertentu mengeluarkan jutaan dolar dalam pembaruan energy.

Sementara, sebagai sebuah perspektif, pendekatan Austrian Economic dapat dipandang sebagai salah satu alternatif pemikiran yang lebih maju dalam memandang kegiatan CSR. Dalam kaitan dengan kewirausahaan sosial sebagai suatu pendekatan dalam mengatasi persoalan sosial dan kemasyarakat; maka CSR dapat sebagai sumber pemecahan masalah sosial tersebut. Beberapa pemikiran Austrian Economics mengenai CSR, adalah sebagai berikut:

1) Wawasan ekonomi dan strategi manajemen mengusulkan bahwa strategi CSR dalam perusahaan harus dipandang sebagai sebuah keputusan investasi dan sebagai suatu cara memperoleh keuntungan kompetitif, sama halnya dengan putusan-putusan investasi lain yang harus diambil.

2) Pendekatan CSR yang berbeda dari Austrian economics berkenaan dengan tindakan kemanusiaan bukanlah berdasarkan 'external constrains' sebagai faktor fundamental pembuatan keputusan.

3) Perspektif Austrian menekankan peluang 'future' dan kewirausahaan aktif dalam mengidentifikasi masa depan.

4) Karakteristik utama keberhasilannya 'capitalist entrepreneurship'; yaitu 
bukan pada kemampuan mereka

beraksi kepada sesuatu atau

'discover' tuntutan eksternal, tetapi

lebih pada kemampuan mereka

dalam membuat keputusan yang

berhasil tentang masa depan (Frynas,

2009; hal.19-20)

Dilihat dari uraian tersebut, konsepkonsep dari Austrian economics dapat lebih berkaitan dengan upaya kewirausahaan sosial di Indonesia khususnya dalam penyelesaian permasalahan sosial dan kemasyarakatan. Sudut pandang kewirausahaan dalam CSR diharapkan dapat memainkan peran kunci dalam membentuk strategi perusahaan memandang permasalahan sosial dan lingkungan.

Sebagai perbandingan dari ketiga perpektif teoritis, dapat dilihat dalam tabel berikut: 
Tabel 2.2 .

Perbandingan Perspektif Teoritis Terhadap Strategi CSR

\begin{tabular}{|l|l|l|l|}
\hline & \multicolumn{1}{|c|}{$\begin{array}{c}\text { Teori } \\
\text { Institusional }\end{array}$} & Teori Stakeholder & \multicolumn{1}{|c|}{ Austrian View } \\
\hline Fokus Utama & $\begin{array}{l}\text { Ketaatan pada } \\
\text { aturan dan } \\
\text { norma }\end{array}$ & $\begin{array}{l}\text { Hubungan dengan } \\
\text { faktor eksternal }\end{array}$ & $\begin{array}{l}\text { Peran } \\
\text { kewirausahaan }\end{array}$ \\
\hline $\begin{array}{l}\text { Determinan } \\
\text { Strategi CSR }\end{array}$ & $\begin{array}{l}\text { Hidup dengan } \\
\text { konteks } \\
\text { kelembagaan } \\
\text { berbeda }\end{array}$ & $\begin{array}{l}\text { Ketergantungan } \\
\text { relative suatu } \\
\text { perusahaan pada } \\
\text { stakeholder }\end{array}$ & $\begin{array}{l}\text { Tinjauan masa } \\
\text { depan } \\
\text { kewirausahaan }\end{array}$ \\
\hline $\begin{array}{l}\text { Lingkup untuk } \\
\text { kebebasan aksi } \\
\text { manajemen }\end{array}$ & $\begin{array}{l}\text { Non-choice } \\
\text { behavior }\end{array}$ & $\begin{array}{l}\text { Pilihan perilaku } \\
\text { terbatas }\end{array}$ & $\begin{array}{l}\text { Pilihan perilaku } \\
\text { yang substansial }\end{array}$ \\
\hline
\end{tabular}

Sumber: Frynas (2009: 122).

\section{PENUTUP}

Seluruh perusahaan dituntut untuk melaksanakan kegiatan CSR tidak lagi semata-mata bekerja untuk mendapatkan keuntungan sebesar-besarnya bagi pemilik modal atau pemegang saham, melainkan juga memberikan manfaat pada masyarakat pada umumnya dan pada komunitas sekitar pada khususnya. Berbagai dampak sosial, ekonomi, dan lingkungan yang timbul akibat berdirinya suatu kawasan industri, mengharuskan perusahaan untuk bertanggung jawab kepada publik melalui aktivitas yang nyata.

\section{SUMBER BACAAN:}

Ackerman, R.W. 1973. How Companies Respond to Social Demands. Harvard University Review 51(4), hal. 88-98.
Namun, di sisi lain, komitmen masyarakat untuk bermitra dengan perusahaan dalam rangka kegiatan CSR masih belum siap. Banyak program kegiatan CSR yang mengarah untuk pemberdayaan masyarakat terhenti di tengah jalan atau tidak sinambung (sustainability). Persoalan teknis yang menyangkut persyaratan administrasi, pelaporan manajemen usaha dan pengelolaan dana nampaknya menjadi kendala utama kelompok-kelompok usaha mikro kecil dan menengah (UMKM) masyarakat.

Alford, H. \& Naughton, M. 2002. Beyond the Shareholder Model of the Firm: Working toward the Common Good of a Business, in S.A. Cortright and M. Naughton (Eds) Rethinking the purpose of Business. Interdisciplinary Essays from the 
Catholic Social Tradition. Notre Dame: Notre Dame University Press.

Cassel, D. 2001. Human Rights Business Responsibilities in the Global Marketplace. Business Ethics Quarterly 11(2), hal. 261-274.

Donaldson, T. \& Dunfee, T.W. 1994. Towards a Unified Conception of Business Ethics: Integrative Social Contracts Theory. Academy of Management Review 19, hal. 252-284.

Donaldson, T. \& Preston, L.E. 1995. The Stakeholder theory of the Corporation: Concepts, Evidence and Implications. Academy of Management Review 20(1), hal. 6591. Davis, K. 1960. Can Business Afford to Ignore Corporate Social Responsibilities? California Management Review 2, hal. 70-76.

Friedman, M. 1970. The Social Responsibility of Business is to increase its profits. New York Times Magazine, September 13th, pp. 32-33, 122, 126.

Frynas, JG. 2009. Beyond Corporate Social Responsibility, Oil Multinationals and Social Challenges. Cambridge: Cambridge University Press.

Garriga, E \& Mele, D. 2004. Corporate Responsibility Theories: Mapping the Territory. Journal of Business Ethic 53: $51-71$

Kaptein, M. \& Van Tulder, R. 2003. Toward Effective Stakeholder Dialogues. Business and Society Review 108 (summer), hal. 203-225.

Lockett, A., Moon, J. \& Wisser, W. 2006. Corporate social responsibility in management research: focus, nature, salience and sources of influence. Journal of Management Studies 43(1), hal. 115-136.

Matten, D., Crane, A. \& Chapple, W. 2003. Behind deMask: Revealing the True Face of Corporate Citizenship. Journal of Business Ethics 45(1-2), hal. 109-120.

Mele, D. 2002. Not only Stakeholder Interest. The Firm Oriented toward the
Common Good. Notre Dame: University of Notre Dame Press.

Prayogo, D. 2011. Socially Responsible Corporation: Peta Masalah, Tanggung Jawab Sosial dan Pembangunan Komunitas pada Industri Tambang dan Migas. Jakarta: UI Press.

Preston, L.E. \& Post, J.E. 1975. Private Management and Public Policy. The Principle of Public Responsibility. New Jersey: Prentice Hall.

Radyati, M.R. \& Nindita. 2008. CSR untuk Pemberdayaan Ekonomi Lokal. Yayasan Indonesia Business Links: Jakarta.

Raharjo. Santoso Tri. 2013. Relasi Dinamis Antara Perusahaan Dengan Masyarakat Lokal (Studi Mengenai Kegiatan Tanggung Jawab Sosial Chevron Geothermal Indonesia, Ltd (CGI) Kepada Masyarakat Lokal Desa Karyamekar Kecamatan Pasirwangi Kabupaten Garut). Disertasi. Program Pasca Sarjana Universitas Padjadjaran. Bandung

Sethi, S.P. 1975. Dimensions of Corporate Social Performance: An Analytical Framework. California Management Review 17(3), 58-65.

Smith, T.W. 1999. Aristotle on the Condition for and Limits of the Common Good. American Political Science Review 93(3), hal. 625-637.

Wartick, S.L. \& Rude, R.E. 1986. Issues Management: Corporate Fad or Corporate Function? California Management Review 29(1), hal. 124-132.

WBCSD. 2002. Corporate Social
Responsibility. The WBCSD's
Journey. WBCSD.

Wheeler, D., Colbert, B., \& Freeman, R.E. 2003. Focusing on Value: Reconciling Corporate Social Responsibility, Sustainability and a Stakeholder Approach in a Network World. Journal of General Management 28(3), hal 1-29. 
Windsor, D. 2001. The Future of Corporate Social Responsibility. International Journal of Organizational Analysis 9 (3), hal. 225-256.

Wood, D.J. 1991. Corporate Social Performance Revisited. Academy of Management Review 16(4), hal. 691-718.

Wood, D.J. \& Lodgson, J.M. 2002. Business Citizenship: From Individuals to
Organizations. Business Ethics Quarterly, Ruffin Series, No. 3, hal. 59-94.

Varadarajan, P.R., \& Menon, A. 1988. Cause-Related Marketing: A Coalignment of Marketing Strategy and Corporate Philanthropy. Journal of Marketing 52(3), hal 58. 